\title{
JUVENTUDE: DESAFIANDO A DEFINIÇÃO PREDOMINANTE ATRAVÉS DOS TEMPOS
}

\section{Youth: challenging the predominant definition through the times}

GROPPO, L A. (2000). Juventude: ensaios sobre sociologia e história das juventudes modernas. Rio de Janeiro: Difel.

Ana Patricia Alves Vieira Parizotto ${ }^{1}$

Maria Juracy Filgueiras Tonelli ${ }^{2}$

É comum observarmos na atualidade inúmeras idéias sobre adolescência e juventude associadas a noções de desordem e crises. Será que tais idéias se mostram coerentes quando se fala nessa população em questão? No livro Juventude: Ensaios sobre Sociologia e História das Juventudes Modernas, Luis Antonio Groppo aborda o conceito de juventude, mostrando que este foi construído histónico, cultural e socialmente. Observa-se que existe uma concepção segundo a qual o ser humano é pensado como um indivíduo que, biológica, mental e socialmente evolui da fase infantil para as fases adultas, sendo a juventude uma fase intermediária.

A obra deixa transparecer sua importância no tocante ao tema em pauta. Escrito de maneira clara, 0 livro cumpre o seu papel de demonstrar e, ao mesmo tempo, informar a maneira como a juventude foi se constituindo ao longo da história da humanidade. Trata-se de um instrumento importante para os profissionais da área das ciências humanas, como também para os profissionais da área da saúde, educação e pesquisadores interessados no assunto.

$\mathrm{O}$ autor pretende com este trabalho discorrer sobre o tema juventude sob diferentes aspectos e olhares. Inicialmente caracteriza a juventude como categoria social, isto é, a juventude nessa perspectiva é vista como uma concepção, representação ou criação simbólica, fabricada pelos grupos sociais ou pelos próprios indivíduos tidos como jovens, para significar uma série de comportamentos e atitudes a eles atribuídos.

O autor afirma que a juventude, como camada social, não apenas passou por várias modificações ao longo dos tempos. Também é uma representação e uma situação social simbolizada e vivida com muitas diferenças na realidade diária, devido a sua combinação com outras situações sociais, assim como às diferenças culturais, nacionais e de localidade, bem como às distinções de etnia e de gênero.

As definições de juventude fundamentam-se em dois critérios que, apesar de terem relações um com 0

1 Psicóloga, mestranda em Psicologia pela UFSC, Professora do Departamento de Psicologia da UNOESC - Campus Joaçaba e UnC - Campus Concórdia.

2 Doutora em Psicologia Social pela UFSC. Docente na UFSC.

Endereço para contato: Rua Ângelo Poyer n.o 8 - CEP 89677.000 - Jaborá - SC.

E-mail parizoto@unoescjba.edu.br

3 MEDRADO, B.; LYRA, J. A adolescência "desprevenida" e a paternidade na adolescência: uma abordagem geracional e de gênero. In: SCHOR, N.; MOTA, M.S.F.T.; CASTELO BRANCO, V. (Org.). Cadernos juventude, saúde e desenvolvimento. Brasília, DF: Ministério da Saúde, Secretaria de Políticas de Saúde, 1999. 
outro, nunca se harmonizam totalmente: 0 criténio etánio e o critério sociocultural. O primeiro sempre presente. O segundo demonstra que o jovem e seu comportamento modificam-se de acordo com a classe social, 0 grupo étnico, a nacionalidade, o gênero, os contextos nacionais e regionais, ainda cabendo apontar que 0 criténio tempo é fundamental para entender tais modificações. Nota-se que a intenção é demonstrar que a categoria social juventude, da mesma forma que outras categonias sociais embasadas nas faixas etárias, apresenta uma importância fundamental para a compreensão de inúmeras caractenísticas das sociedades contemporâneas, bem como o seu modo de funcionamento e suas transformações.

Vale ressaltar que a juventude, ao mesmo tempo em que é vista como categoria social, com características próprias desta fase, também se depara com alguns paradigmas que merecem a nossa reflexão. Um deles diz respeito ao jovem como agente causador de problemas. Tais problemas relacionamse aos rótulos "impostos" pela sociedade que percebe essa fase envolta de significados associados a aspectos negativos, haja vista os termos pejorativos que foram se formando com o passar dos tempos como: "aborrescência", delinqüência juvenil, desagregação. Identifica-se aqui uma relação lógica de causa e efeito: se 0 adolescente representa problemas sociais e risco a si mesmo e à sociedade, é preciso prevenir a sua exposição a determinados fatores, como a gravidez. Conforme observam ironicamente Medrado \& Lyra $(1999)^{3}$ que, adotando a gravidez na adolescência como objeto de análise, afirmam: "não nos surpreenderia se um dia ouvíssemos em uma palestra ou lêssemos em um projeto de pesquisa e/ou intervenção a expressão prevenindo a adolescência".

Outro aspecto que merece reflexão do leitor diz respeito aos termos juventude e modernidade e a relação entre ambos, que pode ser revestida por aspectos tanto de ordem positiva como negativa, como no que diz respeito aos comportamentos que a modernidade espera do adolescente. Relacionar juventude e modernidade significa a aproximação de dois mitos que atualmente desfrutam enorme expansão. O primeiro refere-se ao adolescente dotado de espontaneidade sempre renovada pelas vidas jovens, acompanhada das inúmeras oportunidades presentes. O segundo relaciona-se ao "modernismo", ou seja, a atualidade acompanhada pela rapidez com que a nossa história avança e, ao mesmo tempo, pela necessidade constante de renovação. Mediante tais mitos cabe os seguintes questionamentos: Quais as expectativas da sociedade moderna frente ao comportamento do adolescente? Será que esta mesma sociedade contribui para que este adolescente se desenvolva de maneira "saudável"?Tais questões sem respostas representam alguns dos dilemas com os quais se confronta a humanidade e conseqüentemente a comunidade científica.

As ciências modemas, em destaque a psicologia, apresentam a sua concepção acerca da juventude. A modernidade traz consigo um processo de cerceamento político, policial, moral, empíico e científico do indivíduo. Tais ciências buscam uma definição exaustiva, detalhada e objetiva das fases de maturação desse indivíduo que se encontra em desenvolvimento, bem como propõem métodos de acompanhamento apropriados a cada fase da evolução do indivíduo à maturidade ou idade adulta. No entanto, os conceitos que foram se formando em torno do tema, até mesmo pela própria psicologia, devem ser contextualizados, visto que os jovens representam um laboratónio no qual formas de relacionamento, comportamento, pontos de vista, precisam ser ouvidos e conseqüentemente revistos.

Finalmente, o autor cita a representação da juventude e nazi-fascismo, bem como a juvenilidade e revolução cubana mostrando a sua importância para a compreensão das juventudes ao longo dos tempos, cada uma delas a sua maneira. Conclui nos mostrando que originada da cultura e da sociedade ocidental, capitalistas, burguesas, liberais do século XIX, a nossa concepção de juventude ainda é marcada por caracteres definidores e legitimadores cientificistas, fundamentados em uma noção evolucionista do ser humano e das coisas. Dito de outra forma, uma concepção em que o ser humano é pensado como um indivíduo que, biológica, mental e socialmente evolui da fase infantil à fase adulta, sendo a juventude o que podeníamos chamar de uma fase intermediária.

A leitura do livro será bastante proveitosa para profissionais das áreas das ciências humanas, da saúde e da educação que vivenciam em suas relações sejam de trabalho ou na condição de pais, com adolescentes e/ou jovens, tendo em vista que a obra apresenta um panorama contextualizado do tema, sem, contudo, deixar de propiciar reflexão sobre 0 assunto.

Recebido em/ received in: 10/08/2004 Aprovado em/ approved in: 27/08/2004 